\title{
A BIZTONSÁGTUDATOSSÁG NÖVELÉSÉNEK ESZKÖZEI A FELSŐOKTATÁSBAN
}

\author{
THE TOOLS OF THE INCREASING OF SAFETY \\ AWARENESS IN THE HIGHER EDUCATION
}

\begin{abstract}
Novák János
Óbudai Egyetem, Kollégium, Keleti Károly Gazdasági Kar Vállalkozásmenedzsment Intézet, Biztonságtudományi Doktori Iskola. Cím: 1084, Magyarország, Budapest, Tavaszmezö utca, 7-13; Telefon / Fax: +36-1-6665282, levelezési cím, novak.janos@koll.uni-obuda.hu
\end{abstract}

\begin{abstract}
There comes a time in the life of every family when their child becomes an adult and sets out to put themselves to a great test, going for further studies to higher education institutions. But can we really use the word adult for these youngsters? If looking at it from a teacher's point of view, we surely cannot: we keep seeing them every day, and it is obvious they are still very much children. And if we think deeper, we can see it, once we too, were freshmen. When parents let them go out into a world that is yet unknown to them, the most important concern is to know they're safe. Security consciousness is appearing in many places in higher education. Getting to the school, the hostel living, the rent, the whole environment, the list is endless. But we must mention something that comes with the new world, which is freedom, and the lack of parental control. Many simply cannot handle this and get carried away, some people just can't say no to a friend's invite. And there is yet another serious source of dangers; the Internet. Social media pages, email accounts, video sharing channels, etc. that keep appearing and refreshing are all potential surfaces of attacks, and if we don't have the sufficient means of protection, we can easily fall prey.
\end{abstract}

Keywords: security consciousness, education, higher education, living together, internet.

\section{Összefoglalás}

Sok család életében eljön az az idő, amikor a gyermekük felnőtté válik és nekiindul egy nagy megmérettetésnek, felsőoktatási intézménybe megy tovább tanulni. De vajon használhatjuk-e a felnőtt szót ezekre a fiatalokra? Ha pedagógus fejjel nézzük, akkor biztosan nem, hiszen látjuk őket nap, mint nap és szembe tünik az, hogy ők még nagyon is gyerekek. Ha jobban belegondolunk, láthatjuk is ezt, hiszen mi is voltunk valamikor kezdő egyetemisták. Amikor a szülő elengedi őket abba a világba, amely még ismeretlen számukra a legfontosabb tényező az, hogy biztonságban tudja a gyermekét. A biztonságtudatosság sok helyen jelenik meg a felsőoktatásban. Az intézményekbe való eljutás, a kollégiumi lakhatás, az albérlet, a teljes környezet és még sorolhatnánk. Mindenképpen meg kell említenünk azt, ami velejárója az új világnak, az pedig a nagy szabadság és a szülők kontrolljának a hiánya. Sokan képtelenek kezelni ezt a helyzetet és elúszhatnak az árral, vannak, akik nem tudnak nemet mondani egy-egy baráti invitálásnak. S ezeken kívül még igen komoly veszélyforrást a világháló jelent. A folyamatosan megjelenő és megújuló közösségi oldalak, postafiókok, videó megosztó csatornák stb. mind potenciális támadási felületek, $\mathrm{s}$ amennyiben nem rendelkezünk megfelelő védelemmel könnyen csapdába eshetünk.

Kulcsszavak: biztonságtudat, nevelés, felsőoktatás, együttélés, internet. 


\section{Bevezetés - avagy miért is fon- tos egy felsőoktatási intézmény számára a biztonságtudatosság}

Ha kezünkbe vesszük az írott sajtót és beleolvasunk, vagy csak egyszerủen bekapcsoljuk a televízió készüléket és megnézünk egy híradó müsort. Mit olvasunk? Mit is látunk? Tele van a környezetünkben nem régiben történt negatív események tömkelegével. Ezek sajnálatos módon befolyásolják mindennapjainkat, s ezzel módosíthatják biztonságérzetünket és ezzel biztonságtudatunkat egyaránt. A biztonságtudatosság pszichológiai értelemben határozható meg, amely az érzetet mutatja meg számunkra. Ez az érzet tudatos neveléssel nagymértékben meghatározható és fejleszthető. No de hogyan jelenhet meg a biztonságtudatosság a felsőoktatásban. Azt tudjuk, hogy egy egyetemi kampuszon több ezer hallgató megfordul naponta. Az előadók nagy létszámú csoportok befogadó helyei, a tantermek a kisebb létszámok számára nyújtanak előadási lehetőséget. A diákok, és az oktató kollégák számára fontos a biztonságtudatosság érzete, hiszen napjaik nagy részét ott töltik az intézményben. Amennyiben ezt az érzetet fenn szeretnénk tartani, elengedhetetlen az ehhez szükséges eszközök jelenléte és biztosítása. De melyek is ezek egy oktatási intézmény területén? Fontos, hogy könnyen észrevehetőek, láthatóak legyenek ezek az eszközök, hiszen amit a szemünkkel érzékelünk az egy rögzített, tudatos érzetet nyújthat. Amikor országszerte szinte mindennaposak a tüzesetek, elengedhetetlen a tủzvédelmi rendszer jelenléte egy nagy létszámot befogadó épület esetében. Vezetöje vagyok egy komplett oktatási épületnek - amelyben egyben oktatok is - ahol többszintű tüzvédelmi rendszer van kiépítve. Tudva, hogy a rendszer 100\%-ban müködik engem is biztonságtudattal tölt el, hiszen biztonságban tudom az épületben lévőket. Emellett fontos tényező az állandó porta- szolgálat jelenléte, amely szintén megnyugtató tudatosságot biztosít. Megfelelő szintü kommunikációs eszközökkel jelezzük a menekülési útvonalakat és krízis esetén a tennivalókat. A kollégáinkat folyamatosan képezzük munkavédelmi, tűz- és balesetvédelmi oktatásokkal, amennyiben szükséges akkor a hallgatóságot is (pl. mühelymunka esetén, laborok használatakor). Figyelnünk kell a mindenkori jogi szabályozásnak való megfelelésnek. Fontos a hallgatók és a dolgozók személyi adatainak a védelme [3]. S elérkeztünk ahhoz a sarkalatos ponthoz, amikor említést kell tennünk korunk egyik legdinamikusabban fejlődő ágazatára, az internet világára. A rohanó világunkban elképzelhetetlen egy felsőoktatási intézmény működése a világhálóra való kapcsolódás nélkül. Megfelelő védelmi rendszer nélkül ezt megtenni hatalmas felelötlenség. Érdekesség, hogy egy felmérés alapján a lakosság nagy része nem használ vírusirtó programokat és tüzfalat sem. Gondoljunk csak bele, ha interneten keresztül vásárolunk, akkor mennyi adatunkat tudják megszerezni azzal a néhány kattintással.

\section{Személy- és vagyonvédelem egy felsőoktatási kollégiumban}

A mai rohanó világunk jellegzetességei sajnos megmutatkoznak a felsőoktatásban is. Ahogy az néhányszor említésre került, a mai felsőoktatási rendszer nem igazán alkalmas a közösségi élet kialakítására, s emiatt fontos szerepet tölt be a kollégium intézménye az oktatás mindennapjaiban. Létfontosságú a mai egyetemi hallgatók számára a társas lét, vezetőként látjuk, hogy ez szükséges a növendékeink számára. Emiatt meggyőződésünk szerint egy kollégium, a szociális rendeltetés mellett jelentős nevelési funkciókkal is bír. A mai igényeknek megfelelően egyre több olyan kollégium van jelen a felsőoktatásban, amelyek szinte teljesen összkomfortosak. Ez a hallgatók részérő egy biztonságtudatos légkört 
teremt, de számunkra, üzemeltetőknek további veszélyforrást is jelenthet. Részben a maguk urai, s a lakóegységük - beleértve minden berendezési tárgyat (pl. hütőszekrény) - takarítása is a saját feladatuk. Nem kell bemutatnunk, hogy ez mit is von maga után. Ahhoz, hogy elkerülhessük a higiénia részbeni megszünését, havi rendszerességgel ellenőrzéseket tartunk a szobákban, ezzel némileg növelni tudjuk a hallgatók és a szülők - és nem utolsó sorban a magunk biztonságtudatosságát a tisztaság terén. Miután a kollégiumunk felépült éveken keresztül küzdöttünk az úgynevezett „külsős" személyek nem rendeltetésszerü fogadásával, illetve meg kell említenünk a besurranó hívatlan vendégeket is. Sajnálatos módon több besurranó tolvaj által elkövetett büntény színhelye volt a létesítményünk. Természetesen ez negatívan befolyásolta hallgatóink biztonságérzetét, mi pedig tudtuk, hogy ez nem mehet így tovább és lépnünk kellett ez ügy terén. Kiépítettünk egy kétirányú forgóvillás beléptető rendszert. Azóta teljes mértékben megszünt az illetéktelen személyek itt tartózkodása, és befejeződtek a diákoktól történő eltulajdonítások. Két-három évente elégedettségmérést végzünk a kollégiumban. Az alábbi két ábrán látható, hogy hallgatóinknak milyen mértékü volt a biztonságérzete a beléptető rendszer kiépítése előtt, majd az után (1-2. ábra).

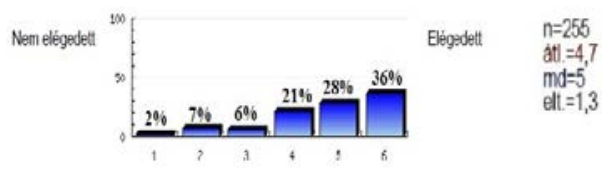

1. ábra. Biztonságtudat a rendszer kiépítése elött (2014)
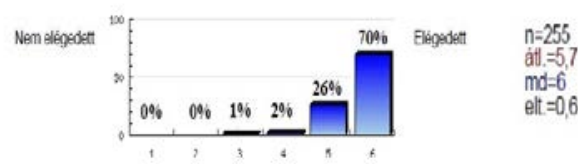

2. ábra. Biztonságtudat a rendszer kiépítése után (2017)
Az említett rendszer mellett még számtalan eszköz segíti a biztonságtudat fenntartását, mint például az épület teljes tüzvédelmi rendszere (füstérzékelők, tüzjelzők, tüzcsapok, tüzzáró ajtók stb.), amelyek megléte oltalmat sugall. Ezt segíti elő az éjjel-nappal müködő recepciós szolgálat is. Indokolt megemlítenünk, hogy a mindennapi élethez szükséges biztonságérzetet is fenn kell tartanunk, mert a szolgáltatás csakis maximális lehet. Ezt úgy tudjuk elérni, hogy állandó karbantartói szolgálat van jelen, és így a felmerülő problémákat azonnal meg tudjuk oldani. Az épületgépészet elemeit a törvényben elöírtak szerint felülvizsgálják és ezt megfelelően számon tartják. Feladatunknak tartjuk, hogy a hallgató szociális ellátása mellett - értjük ez alatt a szállás szolgáltatást - a biztonságos lét tudatosságának fenntartásában, vagy akár a növelésében is segítséget nyújtsunk

\section{Az együttélés normái és attitűd- jei}

Életünk során elkerülhetetlen az együttmüködés, az együttélés folyamata. Ha csak belegondolunk abba, hogy a munkahelyünkön megosztozunk egy munkagépen, vagy ha másfelöl közelítjük meg, akkor egy irodát akár több munkatársunkkal is használhatunk egyszerre. A felsőoktatási tanulmányiank során nagy jelentősége van a megfelelő szocializáció elsajátításához, kialakításához. Ehhez segítségünkre lehetnek a különféle mühelymunkák, csoportos feladatmegoldások, de mégis az egyik legjellemzőbb, egy kollégiumban való együttélés. Ennek közösség építő hatása van, hiszen tudjuk azt, hogy a jelenlegi felsőoktatási rendszerben nincsenek jelen a régi úgynevezett tankörök, amelyeknek meghatározó szerepe volt a rég- és közelmúltban. Szinte az egyetlen színtér ami megmaradt a kapcsolati tőke kialakítására és a közösségi életre nevelésre. Az együttélésnek vannak szabályai. Ismét saját példával élnék, hiszen 
mint intézményvezető nagy tapasztalattal rendelkezem ezen a téren, főleg ha beszámítjuk azt, hogy kilenc éven keresztül voltam jómagam is kollégista. A mai világ sokban különbözik attól, amelyben mi magunk is szocializálódtunk. Mára jellemzővé vált a külföldi hallgatók oktatása is, ami stratégiai szempontból jó az egyetemeknek, de sajnos erre nem biztos, hogy felkészültünk. Ugyanis a harmadik országból érkező diákok szokásai, attitüdjei, normái teljesen eltérőek, a megszokott európaitól. Persze könnyü azt mondani, hogy ha ök jönnek hozzánk, akkor fogadják el azt ami itt jelen van. Ez igaz is lehet, de a törvényi vonatkozásokra. Az együttélés szabályaira nekünk kell megtanítanunk őket, de a legelső feladatunk az kellene legyen, hogy megteremtsük a kulturájuknak megfelelő környezetet és biztosítani a képzett, szakértelemmel és nyelvtudással rendelkező humán erőforrást [2]. A biztonságtudatot növelni kell mindegyik hallgató számára. Itt az együttmüködésben és a közös normák kialakításában, majd elfogadásában kell keresnünk a megoldást.

Timmons (2003) kutatásainak eredményét [1] kissé máshogy értelmezve az alábbiakra juthatunk:

- Elkötelezettség és eltökéltség: ez segít az akadályokon való túljutáson, magába foglalja az áldozathozatali hajlandóságot is.

- Kreativitás és adaptációs készség: egyéni kreativitást és ötletgazdagságot mutatja, a szokatlan ötletek és lehetőségek megragadásának képessége.

- A kockázat, kétértelmüség és a bizonytalanság tolerálása: az ellent-mondásos helyzetek türése.

- Kiválóságra törekvés: saját normarendszer felállítása, a minőség szem előtt tartása.

- Ragaszkodás a sikerhez, lehetöséghez: jellemzi, hogy mennyire tud azonosulni, folyamatos figyelem.
- Vezetés: csapatépítő hajlandóság, bizalom, a másokból való legtöbbet kihozni akarás.

Ezen attitüdöket kellene elsajátítanunk, majd alkalmaznunk, s akkor valószínüsíthető, hogy változik a toleranciánk a más kulturát képviselő hallgatók felé. Természetesen ez nem csak a mi feladatunk, hanem ez rájuk is vár. A jövőt illetően komoly munka áll előttünk. Fel kell készülnünk arra, hogy több hallgató fog érkezni szerte a világból, s nekünk biztosítanunk kell számukra a megfelelő infrastruktúrát, lakhatási lehetőséget és mindezek mellett biztonságérzetük fenntartása is a feladatunk lesz.

\section{4. Összegzés}

Próbáltunk példákat megjeleníteni és ezzel némi betekintést nyújtani a felsőoktatási intézményekben jelen lévő biztonságtudatosságra. Érzékeltettük, hogy igenis szükségszerű a pedagógia jelenléte a egyetemi kollégiumokban. A biztonságtudat jelenléte egyre fontosabb a mai világban, és ennél fogva központi jelentőséggel bír a felsőoktatás területén. Sok tényező befolyásolhatja ezt ebben a környezetben, de nekünk feladatunk, hogy fenntartsuk ezt hallgatóink tudatában. Továbbá célunk ez az érzet esetleges növelése és ennek érdekében a szükséges infrastruktúra és humán erőforrás mindenkori biztosítása.

\section{Szakirodalmi hivatkozások}

[1]. Timmons J. (2003): New Venture Creation, Entrepreneurship for the 21st century, Irwin, Homewood, IL

[2]. John C. Maxwell (2004): Attitüd. Bagolyvár Könyvkiadó, Budapest

[3]. Óbudai Egyetem: SZMSZ, Szervezési és Müködési Rend Kancellária kiegészítése Kollégium, 2017. 